\title{
The struggles of the Central African Republic and Hungary's role in solving the problems
}

\author{
VECSEY Mariann ${ }^{1}$
}

\begin{abstract}
This essay introduces the most important historical facts about the Central African Republic (CAR) to the reader. It researches the roots of the current situation. The essay reviews the first six months of the international intervention. It also describes the changes of the planned European Union (EU) mission, and the role of Hungary.
\end{abstract}

Keywords: Central Africa, Seleka, EU, anti-balaka, Operation Sangaris

In December 2013 fighting intensified in the Central African Republic. Samantha Power, the United States (US) Permanent Representative to the United Nations (UN), said the following about the situation, stating it is "the worst crisis most people have never heard of." [1] The ongoing events in the country have long antecedents. Since it became independent from France the fighting has been continuous, with one coup following another coup, and for decades there has been anarchy in the country. [2] The UN, and the EU, including Hungary, are now involved in the situation, as they have accepted the mounting of an EU mission. [3] Naturally in CAR, like in Mali, a variety of African organisations and interested countries are present. The ongoing events in the Central African country threaten the stability of a volatile region, which is why solving the situation is important for the international community. However CAR suffers from internal problems.

The events in the country have already had an impact on Hungary, because it will deploy troops to the EU mission in CAR. The author considers it to be very important to be familiarized with the country and the fights mainly because of this planned deployment. I would like to introduce the events which led to the current situation in the country, its political situation and the international intervention.

\section{Historical background}

The history of the region goes back thousands of years, but to understand the current crisis I will introduce it from the end of the 1800s. It is important to note that the area has a violent history, for example people were sold into slavery here. The currently existing neighbouring countries also belonged to different colonial empires. Chad and the Republic of Congo belonged to France, the Democratic Republic of Congo was the Belgian king's private colony, Sudan and South Sudan were ruled by Britain and Egypt, Cameroon at first was a Portugese domain, then it belonged to the Dutch, then became a German colony and finally it was ruled jointly by Britain and France. [4] During the fights for possession of different colonies there was a rivalry among Germany, Britain and France for the Central African area. [5] In this fight France was successful and attached the area to France in 1894 under the name of

1 matyasmariann@gmail.com 
Ubangi-Chari. [6: 78-79] In 1910 the area became part of the Federation of French Equatorial Africa. The people who had been exploited by the companies of the colonizing countries revolted in 1928. The three year long fight was not successful, and after the squashing of the rebellion the locals were forced to work under even more brutal conditions. [5]

World War II brought the first noticeable changes: Charles de Gaulle asked for help from the African people and 3,000 people took part in the war. After this, de Gaulle organized the French Union. The first CAR person in the organization was Barthelémy Boganda, who was elected in 1946. Boganda founded the Social Evolution Movement of Black Africa (French: Mouvement pour l'Évolution Sociale de l'Afrique Noire — MESAN) and later on became president of the Grand Council of the Federation of French Equatorial Africa. In this position he supported the coming together of all the tribes to form one nation, but his ideas were rejected. In 1959 Boganda died and after him David Dacko became president. He stayed in his post when the country gained its independence on 13 August 1960, and got its name: Central African Republic. Dacko started a one party regime in the country, and kept the influence of the French companies high in the economy of the country. Because of this the economy of the central African country started to diminish rapidly. [7] Dacko won the elections in 1964, but because of the national bankruptcy and the countrywide strikes in 1965 Jean-Bédel Bokassa led a coup and ousted Dacko from his presidency. The Bokossa era did not improve the situation in the exploited country either. In 1972 Bokossa proclaimed himself president for life and later, in 1976, as emperor and named the country the Central African Emipre. [8] During his rule, Bokossa had a hold on the income of the country's diamond exports. Under the rule of Bokossa the country piled up its debts. In 1979 David Dacko, who was supported by France, led a successful coup. During his second period as president he could only remain in power with the help of French military support, but in 1981 General André Kolingba led a successful military coup, and set up a military dictatorship in the country. In 1986 because of the pressure of the international community a civilian government was formed, but Kolingba remained the real leader of the country. [9]

During the 1990s the democratic movement became stronger in CAR. Because of this Kolingba had to end the one party regime in 1991, and held the first democratic elections in 1992. Ange-Felix Patassé won the elections. [10] The Patassé government inherited a bankrupt state and an unruly population. In response to the turmoil and three attempted coups the government trod all over the personal rights of the citizens executing supposed criminals without trial, and postponing the planned municipal elections, giving bankruptcy as the reason. In 1997 the government, the opposing parties and the religious communities signed the Bangui Agreement, which included the initiation of a wide range of reforms intended to improve conditions in the country. [11]

The agreement did not bring peace to the country. In 1997 France withdrew its troops from CAR, but the UN started a peacekeeping mission only six months later in the country with the name of UN Mission to the Central African Republic (MINURCA). [11] The mission consisted of 1,350 troops, mostly from African countries. The tasks of MINURCA were to re-establish stability and security in the country, plus arrange and monitor democratically successful elections. The mission started in April 1998 and ended in February 2000. [12]

In the elections in 1999 Patassé was re-elected, but the governmental period was not free of tension. In 2003 General Francois Bozizé led a coup supported by foreign countries especially Chad, which led to the end of Patassé’s presidency. Bozizé's interim government wrote a new constitution in 2004, but it did not bring significant changes to the situation of 
the country. However, it was enough to secure Bozizé's success in the 2005 elections. [13] During the Bozizé regime development of the armed forces did not occur and the president's relatives were placed in important positions of authority. [2]

In 2004 fighting flared up again between the armed forces and one of the strongest opposition organisations, Union of Democratic Forces for Unity (French: L’Union des Forces Démocratiques pour le Rassemblement — UFDR), which was led by Michael Djotodia. The headquarters of the organization was in the north-eastern part of the country. The location was important because of the closeness of allied Chadian and Sudanese militias, the lack of governmental power in the provinces and the biggest diamond mines of the country being in that area. $^{2}$ [14] Besides this an important fact is that Djotodia had the support of the local people, because the Muslim minority of the mostly Christian country is concentrated in this region. Besides UFDR other organisations appeared in the area, for example Lord Resistance Army (LRA) which conducts its operations mostly in Uganda. [2]

In 2002 France started an operation to support the African led missions (FOMUC, MICOPAX) in the area, by the name of Operation Boali. [15] The international intervention shook Bozizé's position, and in the "bush war” from 2004 until 2007, he could only hold on to power with French support. During the three year long fight Bozizé had to face loose and uncoordinated allied groups consisting of a few hundred warriors. In the absence of a well trained and equipped armed force, the task of solving the situation remained with the international forces. The fighting started to tail off during 2007 and eventually finished in 2008, with separate agreements with all of the organisations who took part in the fighting, but the agreements were soon violated. Bozizé just wanted to keep his position, and there was no improvement in the country. [2] Because of the fighting nearly 100,000 people fled to neighbouring Chad, which was already unstable because of its internal policy problems and the Darfur conflict. To stabilize the region, the European Union established EUFOR CHAD, in which Hungarian soldiers took part. [16: 394-407]

\section{The Seleka}

In 2012 fighting flared up again between militia groups and the armed forces. The reason for the fighting was the violation of peace agreements signed during 2007-2008. The militia groups, which had taken part in the earlier "bush war", learned that they could only be successful as a united force against Bozizé. At the beginning of the fighting this union consisted of two groups, Convention of Patriots for Justice and Peace (French: La Convention des Patriotes pour la Justice et la Paix - CPJP) and Patriotic Convention for Saving the Country (is a combination of French and Sango words: Convention Patriotique pour le Salut du Kodro - CPSK), but later on UFDR, Democratic Front of the Central African People (French: Front Démocratique du Peuple Centrafricain — FDPC) and The Alliance for the Revival and the Rebuilding (French: L’Alliance pour la Renaissance et la Refondation — A2R) joined too, increasing the number of the allied militia groups to five. [2] The personnel of this united organisation was estimated to be between 1,000 and 3,000, which was a significant force against the undermotivated, undertrained and disorganised armed forces. [17] The name Seleka was used first in December 2012. The name means “alliance” in a local language.

2 The events in Darfur had a significant effect on the stability of the country. 
Seleka, a mainly Muslim organisation, was successful in the north of the country because of the support of the mainly Muslim local people, but soon advanced into the southern parts of the country. Bozizé did not want to solve the situation in the country with negotiations. As a response to this the president of Chad, Idriss Déby, seeing this unwilligness to negotiate by Bozizé, withdrew Chadian troops from the country to stop the crisis before it destroyed the stability of the region. However, in December 2012, not far from Bangui, Chadian soldiers from the MICOPAX mission stopped the advancing Seleka, and under Idriss Déby’s pressure negotiations started with the Bozizé government. [2] An agreement was made in January 2013 which brought noticeable changes, introducing a ceasefire and permitting Bozizé to finish the governmental period until 2016. But soon after Seleka accused Bozizé of violating the agreement. [17] In March 2013 Seleka units continued their advancement on the capital and occupied it on 24 March. After this, Bozizé left the country. [18]

The fleeing of the president made it possible for Seleka to name one of its leaders as president, so in March Michel Djotodia took over leadership of the country and proclaimed himself president. He became the first Muslim president of the mainly Christian country. [1]

\section{The Djotodia government}

After Djotodia gained power anarchy broke out in the country, which led to continous fighting between Seleka and a variety of Christian groups, with the fighting leading to the desolation of villages. The African Union started its African-led International Support Mission to the Central African Republic (MISCA, French acronym for Mission internationale de soutien à la Centrafrique sous conduite africaine) mission in July 2013 with 2,500 troops and started to restore law and order to the country. [19: 7] Djotodia swore the presidental oath in August. The international community was optimistic, and expected the stabilization of the country by the new president, because Djotodia organized and led the Seleka union. However Michel Djotodia wanted to secure his position first, and turned to Islamic countries like Sudan, Qatar and the United Arab Emirates. But neither the neighbouring countries nor the international community would recognise a new Islamic state. [2] The UN called the attention of the international community in August to the possibility that the ongoing events in CAR could shatter the stability of the whole region. [20] Djotodia disbanded Seleka in September, but the majority of the troops did not lay down their weapons, and the militia groups did not finish their fighting. After this the Seleka organisation resisted every kind of external leadership, and demolished villages, looting and massacaring the inhabitants. Because of this violence approximately 400,000 people fled their homes, and about 68,000 sought refuge in neighbouring countries. The actions of the mainly Muslim Seleka called into existence Christian anti-balaka ${ }^{3}$ groups, who can be accused of vigilantism, looting and killing. Christian groups were determined to restore law and order to the country with these methods. [1] The result was a deepening of religious tensions in the country. In October 2013 the UN decided to give support to the African Union led mission in the country, which had deployed in July. [21]

On 5 December 2013, the UN Security Council accepted resolution 2127, in which it allowed French intervention in CAR. [22] At the beginning of December 250 French troops

3 Anti-balaka, that is to say the anti-machete groups, are named after the weapon favoured by the Seleka. 
were deployed to CAR from neighbouring countries to reinforce Operation Boali, ${ }^{4}$ which was based at Bangui airport. With these reinforcements there were now 650 French soldiers in the country [15], with an additional possible reinforcement of 350 troops based in Cameroon. At the beginning of December they decided they would increase the size of the contingent to 1,200 troops. [23] Before the French intervention, like in Mali [24] the country asked for international intervention, with, in this case Prime Minister Nicolas Tiangaye, asking for help from France. [25] On 7 December news arrived of an increase in the number of personnel of the African Union (AU) mission to 6,000 troops. [26] On 10 December the first two French soldiers died during the fighting. [27]

On 5 December the fighting intensified, but it was already on the edge of genocide. On 18 December France had 1,600 troops so far in Operation Sangaris, which was conducting operations in CAR from the beginning of the month. France called on the European Union to support the intervention. Some European countries, for example Belgium, Germany, Spain, Poland and the United Kingdom were already supporting the French intervention in different ways, although they had not sent any troops to the operational theatre. France wanted to change this policy. [28]

On 23 December 2013 the EU banned weapon trafficking and the recruitment of mercenaries to CAR. This ruling was in connection with a UN Security Council resolution accepted in early December concerning the banning of the support for fighting in the country by direct or indirect methods. [29]

On 10 January 2014 President Michel Djotodia and Prime Minister Nicolas Tiangaye resigned because of international pressure, as the international community found it atrocious that the leaders of the country were not capable of putting a halt to the fighting between the Muslim Seleka and Christian groups. [30]

\section{The Samba-Panza government}

After the leaders of the country resigned on 11 January a new interim period started in the Central African Repulic. Alelandre-Ferdinand Nguedet became the president of the Temporary National Council of CAR, [31] of which the most important task was the nomination of an interim president. On 20 January the Temporary National Council nominated Cathrine Samba-Panza, the mayor of Bangui and a neutral politician, to be interim president. [2] It will be her task to organise the oncoming elections, which were brought forward because of the events in the country, to the second half of 2014. Samba-Panza has made great efforts to restore peace to the country, and this is shown by the composition of the interim government: Seleka and the anti-balaka groups could name ministers to it. Samba-Panza's power is guaranteed by the international forces in the country and the compromise between Seleka and anti-balaka groups. This compromise could be a real effort to restore peace, or only just a playing for time, with fighting continuing in the country. Although Seleka and other militia groups withdrew from Bangui on 26 January 2014, the fighting among local groups still had a death toll. [2] In January 2014 the EU decided to deploy a mission to CAR, consisting of 500 troops. The two tasks of the mission were to guarantee the security of the nearly 100,000 refugees at Bangui airport, and to take over some of the French force's responsibilities, so

4 Operation Boali is a French mission in the Central African Republic. It started in 2002. The task of the mission is to protect and secure M'Poko airport in Bangui. 
that Operation Sangaris would be capable of bigger efforts in the area of Bangui. Besides the planned EU mission, president Samba-Panza asked for military help from the UN, but this proposed intervention has conditions attached to it, made by the Secretary-General of the UN in November 2013. If these terms are fulfilled, a 10,000 personnel contingent will be deployed. [32]

On 31 January there were 1,600 French troops in CAR, with an additional 6,000 African troops in the MISCA contingent, consisting of experienced peacekeeping nations, who have already dealt with similar problems, for example Burundi, Chad and Rwanda. [33] Both missions have the same tasks: to restore peace to the country and the protection of inhabitants from militia groups. [34] An additional task is the disarmament of the militia groups, which is highly difficult, because besides firearms they have to collect such weapons as machetes and knives from the warriors too, if they want to put a halt to the fighting. This activity can cause a new problem: the disarmed groups can be attacked by groups who still have their weapons. [2]

Some drew comparisons to the actions committed by the anti-balaka groups with those of the Rwanda genocide of 20 years ago. The fighting in CAR has seen nearly 2,000 deaths, but its dimensions have not reached the level of the Rwandan events in 1994, [35] but on ideological grounds it is similar: it is rooted in ethnic and religious hate. [2] For their protection foreign people were transported home by their parent countries, and a quarter of the 4.6 million population has either fled their homes or been relocated, under the supervision of the UN, to a safer area, usually in a neighbouring country. [36]

At the beginning of February UN Secretary-General Ban Ki-moon called for the reinforcement of the French forces who are staying in the country, and the bringing forward of the deployment of the UN mission because of the critical state in the country. In the opinion of the Secretary-General, the current security situation in the country could lead to genocide, so it is important to increase the number of the peacekeeping troops in the country. Besides this, negotiations started about the integration of the MISCA mission under UN leadership. [37] In February CAR was threatened by severe starvation. Muslim tradesmen, who were being harrassed by Christian militia groups, were leaving their homes in ever increasing numbers, and as a result at the beginning of February around one and a half million people needed emergency food aid according to the UN. But most of the food supplies could not cross the border from Cameroon, because drivers would not undertake the hazards of the journey since the security situation of the country had deteriorated so much. [38]

In the middle of February a mass grave was found, and the accusation of genocide was raised again. The violence grew bigger after Michel Djotodia resigned, despite the units of Operation Sangaris conducting operations in more areas countrywide and the personnel of the MISCA mission being raised. The predominantly Muslim Seleka brought up the possibility of the partition of the country, but president Samba-Panza does not intend to negotiate the giving up the integrity of the country. In connection with the events the possibility of a UN mission was raised again, but until its deployment the Secretary-General asked France to increase the number of its troops in the country. [39]

There were constant negotiations about the establishment of the 500 personnel mission already pledged by the EU. The deployment of the mission was planned for March, but the EU received six more months to reach operational readiness. [40] It is planned that the commander of the mission will be French, which will be of course an advantage in the co- 
operation with the French forces already deployed to the country, as in Mali, where it made communication and cooperation among the missions easier. [41]

In the middle of February a decision was made regarding reinforcement of Operation Sangaris, with France intending to send 400 more troops to the country, thus increasing the number of troops in the peacekeeping operation to 2,000. Besides this, France admitted that the peacekeeping mission would be longer than the planned six months. They need to continue the operation to put an end to the violence. [42]

On 20 February UN Secretary-General Ban Ki-moon asked for the deployment of 3,000 more troops to CAR, and held out the prospect of establishing a UN mission, with around 12,000 personnel in order to protect civilians and to restore stability to the country. In addition, the personnel of the planned EU mission was raised to 1,000 and the MISCA mission now had 6,000 troops in the country. Besides the reinforcement of the operational forces, the UN Secretary-General suggested inmediate financial and logistical support for the government of CAR and the AU forces, who carry out operations in the country. [43]

Operation Sangaris started negotiations with Seleka and anti-balaka groups about the laying down of arms. According to the results from the end of Ferbruary France considered mainly the Christian militia groups an obstacle on the road to peace. The anti-balaka groups were willing to lay down their weapons when Seleka had already done so. [44] But this was not enough a strong enough assurance for anti-balaka groups. They have forced the majority of the Muslim inhabitants to leave, and demolished their homes and shops. The World Food Programme called the international community's attention to this problem because the neighbouring countries who have received the refugees, are slowly being overloaded. [45]

At the end of February the French Parliament voted to extend and enlarge the French mission's mandate. [45] Operation Sangaris, in light of its lack of results, has not been successful as the security situation in the country has hardly changed. Because of this, the UN started talks about establishing a mission with a strong mandate and nearly 12,000 personnel. The mission would take over the currently operating MISCA, and start its tasks on 15 September after bringing it up to its full complement. However, analysts are sceptical about the establishment and the operating ability of such a mission. France would support a UN mission, but the approval of the United Kingdom and the United States of America is not definite, because of the high cost. [46] Besides the UN, the EU has also pledged a mission of 1,000 troops, which would secure the airport. But the establishment of the mission was delayed because the forces and equipment were not forthcoming [47] but as of May 1 the first 150 EU troops have arrived in CAR and have started the handover and take over of Bangui airport from the French mission. [48] Some sources think that the reason for the holding back of forces was the current situation in Ukraine, because the Eastern European countries did not want to send away troops. [49]

Operation Sangaris and MISCA are not enough to restore stability in the country, despite the fact France has extended its former mandate, and we have to reckon with more reinforcements in the future. It was a big loss when Chad withdrew its troops from the country, as they were considered as useful allies, mainly because of their experience in peacekeeping activities. The Chadian government had to redeploy its troops, becase they having been accused of supporting Seleka militia. [50] The UN subsequently gave the go-ahead for the establishment of a mission which would start by taking responsibility for the AU led MISCA mission. [51] The EU pledged 1,000 troops is expected to be mainly French troops with a minimum from 
other nations, but the Ukranian situation resulted in the establishment of this mission only beginning, as already mentioned, on 1 May, 2014. [48] The organising and bringing up to full strength of the UN mission is uncertain. A year earlier, in Mali, the international organisation had to face problems rectifying the personnel and equipment shortages, and CAR does not have the same level of strategic importance as its fellow western African sufferer. So the quick deployment of the UN mission is unlikely, though CAR needs a force which is strong, capable of solving the problems and has the right mandate to stabilize the security situation in the country. [52]

\section{Hungary}

In accordance with the EU decision at the end of January 2014, EUFOR RCA was to be established with a planned personnel of 500, and its task would be the protection of the 100,000 refugees staying at Bangui airport. [40] But because of the deterioration of the security situation in the country, the number of personnel was increased to 1,000, and its tasks changed, with the operational area not only being the airport, but Bangui and its surroundings too. [52] Several large EU countries namely Germany, Italy and the United Kingdom did not commit to sending troops to the EUFOR RCA and this reduced the volunteering of other countries. Despite this, Estonia, France, Latvia, Poland, Portugal, Romania, Spain plus Georgia (a nonEU country) pledged soldiers to the mission. The mission should have been deployed by the end of March 2014, and it would have had six months to reach operational readiness, but the start of the mission was postponed until the beginning of May because of the crisis in Ukraine.

Hungary decided to send some soldiers to the mission on 20 February 2014. The government decided to send a maximum of 6 soldiers, all staff officers, and they would discharge their duties in Bangui and in the operational headquarters of the mission, in Greece. The decision stated that the length of the deployment would be no later than 31 December 2014, or until the end of the mandate should that be earlier. The Hungarian mandate was at the end of March for 9 months, of which the development time would be 3 months and operational time 6 months. The resolution says that Hungary considers taking part in the EUFOR RCA mission an obligation for EU members, and wants to reinforce the Common Security and Defence Policy by taking part in the mission. [53]

This pledge is the result of the NATO withdrawal from Afghanistan, which means a huge decrease in the desired 1,000 troops being deployed at operational level, and the country has to find new opportunities, but CAR role is small compared to the missions in Afghanistan.

\section{Summary}

The situation in CAR is the result of a long process. The fighting has been continous since 1960, when the country gained its independence, but we can relate the present conflict to the fighting which flared up at the beginning of the 2000s. The escalation of the conflict is tied up with the events which happened in March, 2013, but the main reason is that the successive governments have not resulted in any development in the country. There were several international peacekeeping missions in the country, but none of them have been successful. The current mission, not for the first time, arrived late, only when the fighting between the Muslim and Christian groups reminded the international community of the Rwandan genocide. 
The intervention has not brought significant changes to the country, with the situation having deteriorated further, and more disasters threatening the inhabitants.

While France, the AU and the UN seek a solution, only the EU has showed itself supportive, but mainly because of French pressure. The establishment of the UN mission would be vital for the country, but it is not definite that it will have full personnel and equipment, because the country does not have any strategic importance. Because Operation Sangaris has not been as effective as France had hoped, the country wants to solve the rapidly worsening situation with the reinforcement of the troops already stationed in CAR. The EU has wanted to remain in the background in CAR, as in Mali, but the seriousness of the situation calls for a more active role. The task of the 1,000 personnel contingent will be the protection of Bangui and its surroundings including the airport, with the deployment of the mission, having been postponed twice because of the Ukranian crisis starting this week (1 May 2014). [48] Hungary has also pledged a contingent to the EUFOR RCA, so we have to follow the struggles of CAR.

\section{References}

[1] SMITH, D.: Unspeakable horrors in a country on the verge of genocide. www.theguardian. com/world/2013/nov/22/central-african-republic-verge-of-genocide (downloaded: 2912 2013)

[2] MARSAI V.: Válságok Közép-Afrikában II. — Polgárháború a Közép-afrikai Köztársaságban. (Crises in Central Africa II. - Civil war in the Central African Republic.) http://nit.uni-nke.hu/downloads/Elemzesek/2014/SVKK_Elemzesek_2014_4.pdf (downloaded: 2202 2014)

[3] EU troops mandated for Africa mission. www.dw.de/eu-troops-mandated-for-africamission/a-17392818 (downloaded: 2302 2014)

[4] Country Profiles. http://news.bbc.co.uk/2/hi/country_profiles/default.stm (downloaded: 12 01 2014)

[5] The colonial era. www.britannica.com/EBchecked/topic/102152/Central-AfricanRepublic/40700/The-colonial-era (downloaded: 1201 2014)

[6] BESENYŐ J., JAGADICS P., HETÉNYI S. A., RESPERGER I. (2010): Országismertető Csád (Chad, country profile.) Székesfehérvár: Sereg Szemle, 2010.

[7] Independence. www.britannica.com/EBchecked/topic/102152/Central-AfricanRepublic/40700/The-colonial-era (downloaded: 1201 2014)

[8] The Bokassa era. www.bbc.co.uk/news/world-africa-13150044 (downloaded: 1201 2014)

[9] Authoritarian rule under Kolingba. www.britannica.com/EBchecked/topic/102152/CentralAfrican-Republic/214029/Authoritarian-rule-under-Kolingba (downloaded: 1201 2014)

[10] Ban on parties lifted. www.bbc.co.uk/news/world-africa-13150044 (downloaded: 1201 2014)

[11] Patassé and the quest for democracy. www.britannica.com/EBchecked/topic/102152/ Central-African-Republic/214029/Authoritarian-rule-under-Kolingba (downloaded: 1201 2014)

[12] MINURCA. www.un.org/Depts/DPKO/Missions/car.htm (downloaded: 1201 2014)

[13] Patasse ousted. www.bbc.co.uk/news/world-africa-13150044 (downloaded: 1201 2014) 
VECSEY Mariann: The struggles of the Central African Republic and Hungary’s role in solving the problems

[14] BESENYŐ J.: Országismertető — Szudán. (Sudan, country profile.) Székesfehérvár: Sereg Szemle, 2010.; and www.doria.fi/bitstream/handle/10024/77169/StratL2_35.pdf?sequence=1 (downloaded: 2202 2014)

[15] L'opération Boali. www.defense.gouv.fr/operations/centrafrique/operation-boali/l-operationboali (downloaded: 2202 2014)

[16] BESENYŐ J., KOBOLKA I.: Magyar békefenntartók Afrikában. (Hungarian peacekeepers in Africa.) Budapest: Katonai Nemzetbiztonsági Szolgálat Tudományos Tanács, 2013.

[17] WARNER, J.: Who are Seleka? http://globalpublicsquare.blogs.cnn.com/2013/01/17/whoare-seleka/ (downloaded: 1201 2014)

[18] The 21st century. www.britannica.com/EBchecked/topic/102152/Central-AfricanRepublic/254026/The-21st-century (downloaded: 1201 2014)

[19] SMITH, D.: France to bolster forces in central Africa. The Guardian Weekly, 06 December 2013.

[20] Bozize ousted. www.bbc.co.uk/news/world-africa-13150044 (downloaded: 1201 2014)

[21] MTI: Döntött az ENSZ BT: rendet kell tenni a Közép-afrikai Köztársaságban. (The UN Security Council decided order must be restored to the Central African Republic.) http://hvg. hu/vilag/20131010_Dontott_az_ENSZ_BT_rendet_kell_tenni_a_Ko/ (downloaded: 1201 2014)

[22] UNSCR: Resolution 2127. Central African Republic. http://unscr.com/en/resolutions/2127 (downloaded: 1201 2014)

[23] UPDATE 1 - France deploys troops to secure CAR capital after clashes. www.reuters.com/ article/2013/12/05/centralafrican-france-idUSL5N0JK2NO20131205 (downloaded: 1201 2014)

[24] BESENYŐ J.: The European Union mission in Mali - Hungary's involvement in the mission. Contemporary Military challenges / Sodobni Vojaski Izzivi, 11 (2013), 25-37. www.slovenskavojska.si/fileadmin/slovenska_vojska/pdf/vojaski_izzivi/svi_15_3.pdf (downloaded: 1201 2014)

[25] Central African PM urges France to act quickly to stop violence. www.reuters.com/ article/2013/12/05/us-centralafrican-fighting-pm-idUSBRE9B40SJ20131205 (downloaded: $10012014)$

[26] African Union to nearly double troops in CAR to 6,000: France. www.reuters.com/ article/2013/12/07/us-centralafrican-france-union-idUSBRE9B60B120131207 (downloaded: $12012014)$

[27] French soldiers killed in Central African Republic. www.bbc.co.uk/news/worldeurope-25313817 (downloaded: 1201 2014)

[28] IRISH, J., FELIX, B.: France says EU countries to send troops to Central African Republic. www.reuters.com/article/2013/12/18/us-centralafrican-france-idUSBRE9BG0Y020131218 (downloaded: 1201 2014)

[29] LEWIS, B.: EU bans arms exports to Central African Republic. www.reuters.com/ article/2013/12/23/us-centralafrican-france-eu-arms-idUSBRE9BM0BC20131223 (downloaded: 1201 2014)

[30] Central African Republic president and prime minister to resign. www.theguardian.com/ world/2014/jan/10/central-african-republic-president-pm-resign (downloaded: 1201 2014)

[31] UPDATE 2 - C. African Republic's capital tense as ex-leader heads into exile. www. reuters.com/article/2014/01/11/centralafrican-idUSL6N0KL0BE20140111 (downloaded: 12 $012014)$ 
[32] NICHOLS, M.: Central African Republic wants U.N. force as EU troops OKed. www. reuters.com/article/2014/01/29/us-centralafrican-eu-un-idUSBREA0R1FD20140129 (downloaded: 2202 2014)

[33] NIKOLAEVA, M.: France likely to extend mission in Central African Republic: minister. www.reuters.com/article/2014/02/06/us-centralafrican-france-idUSBREA151BP20140206 (downloaded: 2302 2014)

[34] Sangaris: point de situation du 31 janvier 2014. www.defense.gouv.fr/operations/ centrafrique/actualites/sangaris-point-de-situation-du-31-janvier-2014 (downloaded: 2202 2014)

[35] BRAUN, E.: Eight dead in Central African Republic capital, rebel leaders flee city. www. reuters.com/article/2014/01/27/us-centralafrican-idUSBREA0P0O220140127 (downloaded: 2202 2014)

[36] NGOUPANA, P-M.: Central African Republic's capital tense as ex-leader heads into exile. www.reuters.com/article/2014/01/11/us-centralafrican-idUSBREA0A0IL20140111 (downloaded: 1301 2014)

[37] NICHOLS, M.: U.N.'s Ban to France: Mull more troops for Central African Republic. www.reuters.com/article/2014/02/11/us-central-african-un-idUSBREA1A2AK20140211 (downloaded: 2202 2014)

[38] FLYNN, D.: RPT-Muslim exodus threatens food crisis in C. African Republic. www.reuters. com/article/2014/02/12/central-african-food-idUSL5NOLG4CO20140212 (downloaded: 23 02 2014)

[39] KOKPAKPA, S. L.: Mass grave found in Central African Republic; U.N. warns of "cleansing”. www.reuters.com/article/2014/02/12/us-central-africanidUSBREA1B1PF20140212 (downloaded: 2302 2014)

[40] CROFT, A.: EU force to create "safe haven" in Central African Republic. www.reuters. com/article/2014/02/13/us-centralafrican-eu-idUSBREA1C1SX20140213 (downloaded: 23 02 2014)

[41] BESENYŐ J.: Az Európai Unió kiképző művelete Maliban és a magyar szerepvállalás. Honvédségi Szemle, 1415 (2013), 68-76. www.honvedelem.hu/container/files/ attachments/40386/hsz_2013_5.pdf (downloaded: 2302 2014)

[42] de La HAMAIDE, S.: French minister says CAR operation to last longer than expected. www.reuters.com/article/2014/02/15/us-centralafrican-france-idUSBREA1E0J120140215 (downloaded: 2302 2014)

[43] NICHOLS, M.: U.N. chief wants 3,000 more troops for Central African Republic. www.reuters.com/article/2014/02/21/us-centralafrican-un-idUSBREA1J21R20140221 (downloaded: 2302 2014)

[44] MEDIA COULIBALY: Central African Republic militia says will only disarm after Muslim rebels do. www.reuters.com/article/2014/02/22/us-centralafrican-militiaidUSBREA1L0T620140222 (downloaded: 1703 2014)

[45] KOKPAKPA, S. L.: Armed groups surround thousands in Central African Republic: U.N. www.reuters.com/article/2014/02/25/us-centralafrican-violenceidUSBREA1O1IM20140225 (downloaded: 1703 2014)

[46] CHARBONNEAU, L.: U.N. proposes Central African Republic peacekeeping force. www.reuters.com/article/2014/03/03/us-centralafrican-un-idUSBREA221UL20140303 (downloaded: 1703 2014) 
[47] IRISH, J.: France says EU shirking duty to Central African Republic. www.reuters.com/ article/2014/03/14/us-centralafrican-france-eu-idUSBREA2D0VS20140314 (downloaded: 1703 2014)

[48] CROFT, A., BRAUN, E.: EU peacekeepers take charge at Central African Republic airport, violence rages. www.reuters.com/article/2014/05/01/us-centralafrica-euidUSBREA3T12620140501 (downloaded: 0205 2014)

[49] CROFT, A.: Ukraine crisis hampers EU's Central African Republic mission. www.reuters. com/article/2014/03/14/us-centralafrica-eu-idUSBREA2D1QX20140314 (downloaded: 17 03 2014)

[50] IRISH, J., NAKO, M.: Chad to withdraw troops from AU mission in Central African Republic. www.reuters.com/article/2014/04/03/us-centralafrica-idUSBREA320YT20140403 (downloaded: 0404 2014)

[51] NICHOLS, M., DEMBASSA-KETTE, C.: U.N. Security Council OKs peacekeepers for Central African Republic. www.reuters.com/article/2014/04/10/us-centralafrica-unidUSBREA391OE20140410 (downloaded: 1104 2014)

[52] IRISH, J., FLYNN, D.: France risks long stay after misjudging Central African Republic. www.reuters.com/article/2014/02/23/us-france-centralafrica-insightidUSBREA1M0PW20140223 (downloaded: 2302 2014)

[53] MTI: Döntött a kormány a közép-afrikai magyar katonai szerepvállalásról. (The govenment has decided concerning the Hungarian military's participation in Central Africa.) www. honvedelem.hu/cikk/42508 (downloaded: 2202 2014) 